\title{
INTERACTION BETWEEN FAMILIES OF CHILDREN WITH SPECIAL NEEDS AND SUPPORT SYSTEM: PARENTAL PERSPECTIVE
}

\author{
Dina Bethere \\ Linda Pavitola \\ Liepaja University
}

\begin{abstract}
The study analyses the effectiveness of interaction between parents, who bring up children with special needs and the support system. According to the state defined standards and cognitions of scientific research, activities of the support system are considered as qualitative only if they satisfy parents' individual needs of receiving support. The article reflects qualitative research, where parents have naturally been delegated the functions of experts. The results of the study verify the necessity to improve collaborative strategies, employing non-governmental organizations as a resource for promoting collaboration between parents of children with special needs, educational and support institutions.
\end{abstract}

Keywords: children with special needs, collaboration, effectiveness, parents, provision of support.

\section{Introduction}

The concept of family in scientific categories have been defined as a social institution, where a child obtains the first experience of socialization and where preparation for future roles and tasks in the society occurs within interpersonal system of attitudes (Шнейдер, 2008). At the same time, family environment have been consistently perceived as a protected space with its traditions, habits and requirements, existing between the individual and demands of society (Praschak, 2003).

Parents have been delegated supreme responsibility for ensuring life and developmental conditions of their children, defining the duties and rights in accordance with protection of the child's rights and interests that allow choosing educational institution and participating in a study process development. In their turn, a duty of parents bringing up children with special educational needs (SEN), is to provide special care for their child. Thus, the parents of children with SEN are considered as equal and active partners of various institutions like health care, educational and others. In this regard governmental structures on international scale have been also delegated duties to finance and make available a range of high-quality services from which the families of children with disabilities can choose assistance adapted to their needs (Recommendation of the Committee of Ministers, 2010).

Implementation of these demands is topical to all European Union partner states and refers to every person engaged professionally in the support system foreseen for children with SEN and their parents. Correspondingly the parents as the target audience and collaboration partners of the system mentioned above, have 
been considered as the main quality experts of its functioning. This cognition served as a basis for the study reflected in the article.

The aim of the study was to examine parents understanding of their role in the process of special education for their child with SEN in the context of interaction between a family and a support system, taking into consideration the existing relationships between family members and attitudes in social environments.

Methods of the study: 1) analysis of scientific literature, 2) stratified sampling, 3) narrative analysis.

\section{Conditions for effective interaction between support system and parents}

In different periods of time research findings in pedagogy, family psychology and crisis theory certify that care about children with SEN has been considered as one of the most complicated life trials (Bach, 1993; Buscaglia, 1971; Dillon \& Underwood, 2012; Jetter, 2003; Lāgerheima, 2007). The authors of the article regard it as one of the most relevant cognitions to be respected by specialists of different support areas, implementing their professional duties and developing collaboration with parents of children with SEN.

One of the indicators of this specific situation is particular psychological climate in a family microsystem. Children with SEN usually express heightened necessity for security, love and empathy, accompanied with trials about their personal helplessness and loneliness (Целуйко, 2004). Although there is stated a demand for parental love, responsibility and promotion of child development, the accomplishment of the demand is often hindered by parents' sense of guilt and necessity to reveal intimate family life aspects in the communication process with experts of different areas. Thus the specifics of a child's development and influence of social environment create discrepancies in implementation of the social role of parents (Lāgerheima, 2007).

Changes characteristic to the child's socialization bring forward new challenges in relationships between family members. According to the findings of psychological research, the attitude of children towards extended environment depends on acceptance of their individual needs and developmental expressions, characteristics of communication, organization of interaction and achievement evaluation in the family microsystem (Усанова, 2006).

At the same time these families have been characterized by limited social activity and external contacts. Thus increasing inner contradictions in the functioning of family microsystem, the scope of problems to be solved has been broadened and direct dependency on collaboration with different social and health care institutions has been increased (Engelbert, 2000).

In accordance with the way parents overcome the contradictions mentioned before, families can be divided into two groups: microsystems, where functional coping occurs without particular problems and families, who need differential 
support in diverse areas. However, representatives of both groups need to have information about existing situation, developmental disorders, parental understandings and expectations that are meaningful because of their psychological context. Providing this information the parental coping phase has to be taken into consideration (Neuhäuser, 2003: 85).

Recently the conceptions of the effectiveness of support system functioning have been changed in connection with parental co-partnership. If before a family of children with SEN had been studied more as a background, where problems arise, then now it is considered as a meaningful social institution for a child (Jetter, 2003). Correspondingly the studies in the area of special pedagogy have broadened the view of family institution orienting the work of different specialists towards awareness of family resources. Thus the parents of the child are no longer considered as objects of special pedagogy, but perceived as competent partners of collaboration possessing equal rights (Theunissen \& Plaute, 1995). Parents have their comprehension and needs obtained during their life path, as well as the resources that can be used to overcome problematic situations. These resources can be broadened acquiring skills of selforganization and learning to ensure the rights (Buscaglia, 1971; Praschak, 2003). In this context it has to be taken into consideration that parental perception of disadvantaged children are not homogenous and much focused on the individual case (Dillon \& Underwood, 2012). The longitudinal study verifies the diversity of needs and a desire of parents to understand the types of academic and behavioural support their child is receiving, particularly when he or she is struggling. Many parents also want to know how they can help their child to be more successful. Nevertheless, parents may not always be able to grasp the educational terminology that teacher use or the practical implications of those terms for their child (Byrd, 2011: 34).

Thus, ensuring parental collaboration in the support system, the duties of experts include the understanding of particular family needs to examine the suitability of recommended support. At the same time it is necessary to use forms of work that facilitate participation of parents in a common work. Orientation towards the needs of parents means ensuring a link between scientific approach and practical activities, and developing service conception that includes innovative offers and a parent-friendly interaction. These are considered as the most sufficient conditions for effective support system activity, as the quality is present if the needs of the client have been satisfied and a support offer corresponds with parental expectations (Jansen \&Wenzel, 1999).

Evidence-based cognitions of scientific studies certify that implementation of the conditions characterized above is a significant investment in both the functioning of family microsystem of children with SEN and the development of support system itself. Close working relationships between professionals and family members also ensure that service recommendations are flexible, accessible and responsive to family needs (Angelo, 1997; Parette \& Brotherson, 
1996; Thomson, Meadan, Fensler, Alber \& Balogh, 2007), as the family is the constant in the child's life, while service and professionals within the system are always in a state of flux (Shelton, Jeppson \& Jonson, 1987). It enables people having diverse experiences to interact sharing the common goal of reaching agreement on specific issues. Such interaction can result in shared ownership of problem definition and solutions, shared knowledge and expertise, increased cohesiveness and willingness to work together on future issues (Rock, 2000; Thousand, Villa, Paolucci-Whitcomb \& Nevin, 1996; Salend, 2004).

It has been noted that the basis of effective partnership development requests not only constructive, but also emotional aspect. This means the readiness to develop equal interaction and achieve mutual understanding in this process has to be reciprocal. Very often it is a challenge for both parents of children and specialists of support system. However, L. Buscaglia beliefs can be useful for ensuring positively loaded emotional link: „But I do have an enormous love for parents, and the sum of what I am going to say is this: as far as I am concerned, it is about time professionals began to look at parents as warm, pulsating, beautiful, tender, fantastic, unbelievable, intelligent, incredible human beings. And then I want to discuss how parents and professionals can work together, for as long as parents are trapped with professionals and professionals are trapped with parents, we are going to have to find a way to reach one another" (Buscaglia, 1971: 27).

The totality of multidimensional conditions for ensuring the effectiveness of interaction between the support system and parents of children with SEN, as well as its constructive and emotional aspects have been analysed in the study performed by the authors.

\section{Research design}

\section{Participants}

The study was performed in 2013 during annual summer camp organized by the non-governmental organization (NGO) ,Velku biedrība”. The participants were 23 parents of children with SEN representing diverse regions of Latvia. The parents in the study had children of different age and educational levels, enrolled in preschools or schools`environments that ranged from full time placement or general education classrooms to self-contained classrooms or separate schools. They had diagnosis like autism spectrum disorders, severe movement and mental development disorders.

\section{Research method and procedure}

The ecosystem study was implemented in real life environments and characterizes interaction of different microsystems in parents' social life. The participants of the study were recruited using a strategy of stratified sampling and a qualitative research method of narratives was selected.

Beginning the research process parents were given general guidelines for the content of narratives - for example, reflection of family interaction with society, 
educational institutions and external support system. The "Velku biedrïba" acted as observers, they fixed and anonymised the narratives, and negotiated with the parents on making them available to public. The narratives reveal the existing life situation in diverse microsystems, parents ' understanding about the contexts in the field of special education and help to interpret their experiences in the process of interaction between the family and the support system.

To analyse and interpret the data and derive meaning from parents' shared experiences, the authors of the study identified core categories based on the research instrument used by P. Lalvani (2012). The data was coded by the authors, and according to the narratives the following categories were defined:

- Parents` understanding and needs in the context of special education;

- Interaction between the family and the support system in social environment with: a) educational institutions and professionals, b) other professionals;

- Parents as educators un advocates;

- Parents as students.

In order to reveal the context of the study, the analysis of narratives contains the characteristics of the family microsystem`s inner functioning.

\section{Results}

The indicators of the family microsystem's inner functioning reveal differences reflected in the narratives. Some parents have mentioned positive examples like: ,We are three in the family and both take care of the child. We teach communication making him easier to form relationships with other people." There is also some evidence about parents' mutual support in complex life situations: „My husband understood me and was able to take responsibility for both of us."

However, majority of narratives report family breakdown just because of special needs of a child: „Child's father told that he did not want to be dependent on the special needs and demands of the child." Moreover, in some cases parents express fear of such situations: „I was afraid that my husband could leave us, as we know about similar situations in other families."

The study demonstrates parents ' understanding and needs in the context of special education. Parents have their opinions about special education and are aware of social and educational needs of their children according to the rough life experience acquired in seeking for the best possible educational environment for their child. Majority of parents believe in education as an opportunity for their child's well-being, equality and social integration: „We have to find a proper educational institution instead of social care institution - home for disabled. Children want to live in a family and be members of society like others."

The overwhelming majority of parents are aware of the diagnosis of their child and try to cope with it and provide the best possible options for their child. They 
long for wider offer of non-formal education, for example, musical activities and movement therapy, and conclude that children's life after school is only parental responsibility, as "the offer provided by the state and municipality is extremely modest".

However, most of the parents express worries about the quality and outcomes of the educational process that very often mismatch their hopes and expectations. For example, a mother points to the observed changes in her daughter's behaviour: "She has begun to command - claps hands and loudly cries out commands like "stand up", "wait" and others. There is no such kind of communication in our family and it is not supported as well." Many of the parents have come to the conclusion that ,the school was not completely ready for educating children with autism spectrum disorders" and express concern about the competence of pedagogues: „My child has poorly developed language and literacy skills. I felt disappointed with the pedagogue, who was not able to explain how these skills could be improved". The parents share the belief that their children need learning environments with appropriate specialists, who pay more attention to the development of social and everyday skills.

The study has reflected interaction between the family and the support system in social environment with educational institutions and professionals. The findings indicate a diversity of educational opportunities that are recommended by professionals and used by children with SEN - ranging from home education, specialized preschools, inclusive general preschools and schools to special schools. Parents have reported that although there are special programmes for children with SEN in general schools, not always they feel welcome: ,School's administration acknowledged that they are not interested to have children with SEN in their school".

According to the narratives, the presence of negative attitude has often been identified in the very beginning of the educational process, for example: ,I went to school to talk with the administration and the class teacher in due time. Their attitude was not negative, but it seemed like they were waiting that all this somehow would slip by. All collaboration was confined to my talking".

The findings reveal other significant aspect - schools lack experience and qualified pedagogues to implement special programmes: ,, The pedagogue of special education, a lady of pension age, honestly confessed that she is not able to work with my child". In the context of special education provision parents emphasize a lack of responsibility of pedagogical staff: ,When I went to school, I saw the support personnel chatting instead of taking care of children”.

In contrary to above mentioned, there are also narratives that express positive evaluation and satisfaction with "educational opportunities recommended by the state and municipality that offer both inclusive preschools and special education institutions". It is highly valued if the parents of other children express understanding. 
According to the findings, the experience of interaction between the family and the support system in social environment with other professionals has been characterized as negative. All parents have reported disappointment they experienced at the State Pedagogical Medical Commission (PMC) that evaluates their child's diagnosis, characteristics of specialists and recommends a learning environment and educational institution the most appropriate for the child.

The parents note that specialists are not interested to understand the child's problems and their conclusions are superficial, since it is not possible to evaluate a child with autism in a few minutes time in an unfamiliar environment. The narratives reflect reasonable objections that PMC determining the fate of the child does not evaluate individual opportunities, therefore parents do not perceive the work of the commission as meaningful. A typical viewpoint of parents is: „Majority of PMC consists of pension age ladies with soviet education and thinking. They have minimal interest in children, their needs and potential. The conclusions of specialists are superficial and it feels like the conclusion is needed just to apply a seal to the child - "fit" or "unfit".

Many parents express objections about the style of work of these institutions: „Nobody even asked me, which school I would prefer to my child! It was clear to them, which school to attend. I did not agree.... They even did not give a chance to try!" The parents are also anxious about professional ethics of these specialists: „, They spoke so negatively about my son! The worst is that he heard everything, as he was next to me".

The narratives reveal that parents feel discriminated about inaccessibility to the premises of the State PMC in the centre of Riga, which is located on the second floor with non-functioning elevator and a distant parking place.

The narratives certify that parents are very conscious about their role as educators of their children and act as educators and advocates. Among the questions asked the most frequently are the following: How will the school be able to implement the programme of special education? Which school to collaborate with? If a child is not able to adapt to the learning environment what to do? Change the school? Leave in the boarding school? Economic situation often is a reason for inability to solve the problem: ,Because of work, it is not possible for me to change the school-nowadays it is a risk to change work, in order to adapt to my child's schedule". Even if the parents have found the school and the child feels well there, they have to give up learning, as they do not have money for taking the bus to school.

The narratives verify that parents are interested in the learning process of their child and desire to know more from the pedagogical personnel - what was done during lessons and free time activities, what was acquired, how was behaviour like. In this context the information exchange by the help of a diary is unacceptable, as it does not reflect all activities performed by a child. Therefore parents have a feeling that records have been done carelessly. Sometimes parents take part in the learning process and try, in the frame of their 
possibilities to be side by side with their child during activities like music, sports and arts, as well as to go on excursions together with the class".

The narratives of parents present a tendency of implementing the routine characteristic to educational institutions in the family environment, for example, "we try to implement structured daily routine” or ,every day we devote at least 30-40 minutes to the feasible tasks for the child".

Judging the narratives, there are some cases when developmental exercises have been organically included into the daily routine of the family: ,A day before the event I prepare my child. I use pictures - pictograms to complement what has been told" or ,We do not help our child with a lot of things rather try to teach him how to manage on his own".

The narratives reveal the role of parents as students - they have acquired knowledge about their child's diagnosis, needs, educational and developmental possibilities due to their motivation, perseverance and personal experience. Majority of parents acknowledge that they have received a purposeful support for their development from NGO: "Due to their suggestion we started to look for a school" or "During the summer camp organized by NGO I have gained new points of view, positive emotions, many ideas how to work with my child". Comparatively typical is the following conclusion about the existing situation: "The most important - I am convinced that I have a smart child; the only thing he needs is an appropriate approach and knowledge."

\section{Discussion and conclusions}

The results of the study verify the diversity of the families of children with SEN that were involved in the research process. Applying the classification of G. Neuhäuser (2003), the selected samples represent both - the parents having comparatively successful experience of undergoing the phases of coping and parents, who experience negative emotions and sadness. It is possible that exactly the regularities of the family microsystem 's inner functioning influence parents' abilities to facilitate the process of family socialization in society. It is comprehensible that upbringing of a child with SEN demands particular care; however, explanation of parents' social role and encouragement of acceptance of its aspects have not been considered as a part of the educational system's tasks. In national level not only possibilities of financial character should be provided for these families, but also availability of therapeutic aid.

The parents involved in the study consentaneously recognize education as a particular value for their children. However, according to the Latvian legislation, ensuring educational opportunities is highly dependent upon local municipalities or conclusions made by the PMC, which duties also include consulting for parents. Indeed, it is possible that these institutions employ experts with appropriate professional qualification and experience, however, the narratives express discontentment with their functioning. Therefore, improvement of professional qualification or even certification of the PMC experts has to be 
considered, turning particular attention to the aspects of communication skills development and professional ethics comprehension.

Regarding to the lack of understanding and worries about the special education process and the quality of its outcomes, one of the main concerns of parents is frequent change of teachers, caretakers or even educational institutions that make their children to feel gloomy, shy and nervous. The attitude and sensitivity of teachers is of great importance, as children with SEN easy adopt the observed models of behaviour. There are problems also with inclusion in general education and communication with support team experts - psychologists, social pedagogues and speech therapists that in spite of their education and work experience are not able or willing to help the child with SEN. Instead of giving support, they refer to other specialists. Often parents, in accordance with their perceptions, try to create the environment at home similar to that at the educational institution; however, the parents should devote more time exactly for the development of emotional contact with their child.

This situation could be explained by the findings of G. Dillon \& J. Underwood (2012) certifying that parents usually concentrate only on their own child's special needs and do not perceive educational institution as a complex microsystem, whose functioning differs from family environment. Because of this, educational institutions have to initiate mutual communication and plan effective collaboration strategies with families, developing both constructive and emotional contacts. Therefore the professional programmes of further education should ensure opportunities to acquire the competences necessary for planning interaction with the parents of children.

Significant resource for creating collaboration strategies between parents, educational and support institutions could be NGO that unite families of children with SEN. The results of the study verify that exactly in the frame of these organizations parents have opportunity to learn by doing and communicate in an emotionally friendly environment. Moreover, developing collaboration with NGO, parents could gain an invaluable partner. This is proved by the quality and quantity of research data and allows planning further research, implementing ecosystem approach and reflecting multiperspective view on the essence of identified problems and their possible solutions.

The authors of the article have put forward the following questions for the discussion and further research: 1) necessity for professional improvement of the PMC experts, 2) development of collaboration strategies between educational institutions and parents of children with SEN, 3) use of NGO resources to create collaboration among parents, educational and support institutions. 


\section{References}

1. Angelo, D. H. (1997). AAC in the Family and Home. In: S. Glenn, D.De Coste (Eds.), The Handbook of augmentative Communication. San Diego: Singular, 523-545.

2. Bach, H. (1993). Geistigbehindertenpadagogik. Ed.Marhold im Wiss.-Verl. Spiess.

3. Buscaglia, L. F. (1971). Parents Need to Know: Parents and Teachers Work Together. In: J. I. Arena (Eds.), The Child with Learning Disabilities: His Right to Learn. Pittsburg: Association for Children with Learning Disabilities, 27 - 40.

4. Byrd, E. S. (2011). Educating and Involving Parents in the Response to Intervention Process: The School's Important Role. Teaching Exceptional Children, 43(3), 32 - 39.

5. Dillon, G.V., Underwood, J.D.M. (2012). Parental Perspectives of Students with Autism Spectrum Disorders Transitioning From Primary to Secondary School in the United Kingdom. Focus on Autism and Other Developmental Disabilities, 55(2), 81-92.

6. Engelbert, A. (2000). Familie und institutionelle Umwelt: ein Beitrag zur Sozialökologie der Entwicklung von Kindern mit Behinderungen. In: M. Grundmann, K. Lüscher (Hrsg.), Sozialökologische Sozialisationsforschung. Konstanz: Universitätsverlag, 203-225.

7. Jansen, F., Wenzel, P. (1999). Von der Elternarbeit zur Kundenpflege. München: Don Bosco.

8. Jetter, K. (2003). Famielien heute. In U. Wilken, B. Jeltsch-Schudel (Hrsg.), Elter behinderter Kinder: Empowerment-Kooperation-Beratung. Stuttgart: Verlag W. Kohlhammer, 15-30.

9. Lāgerheima, B. (2007). Es arī attīstos! Rīga: Velku biedrība.

10. Lalvani, P. (2012). Parents` Participation in Special Education in the Context of Implicit Educational Ideologies and Socioeconomic Status. Education and Training in Autism and Developmental Disabilities, 47(4), 474-486.

11. Neuhäuser, G. (2003). Diagnose von Entwicklungsstörungen und Coping-Prozesse in der Familie als ärtzliche Aufgabe. In: U. Wilken, B. Jeltsch-Schudel (Hrsg.), Eltern behinderter Kinder: Empowerment-Kooperation-Beratung. Stuttgart: Verla W. Kohlhammer, $73-89$.

12. Parette, H. P., Brotherson, M. J. (1996). Family participation in assistive Technology Assessment for young Children with Disabilities. Education and Training in Mental Retardation and Developmental Disabilities, 31(1), 29 - 43.

13. Praschak, W. (2003). Das schwerstbehinderte Kind in seiner Familie. In: U. Wilken, B. Jeltsch-Schudel (Hrsg.), Eltern behinderter Kinder: Empowerment-KooperationBeratung. Stuttgart: Verlag W. Kohlhammer, $31-42$.

14. Recommendation CM/Rec (2010)2 of the Committee of Ministers to member states on deinstitutionalisation and community living of children with disabilities. (2010). Available: https://wcd.coe.int/ViewDoc.jsp?id=1580285.

15. Rock, M. L. (2000). Parents as Equal Partners. Teaching Exceptional Children, 32(6), $30-37$.

16. Salend, S. J. (2004). Fostering Inclusive Values in Children: What Families Can Do. Teaching Exceptional Children, 37(1), 64 - 77.

17. Shelton, T. L., Jeppson, E. S., Jonson, B. H. (1987). Family-centred care for Children with Special Heath Care Needs. Washington, DC: ACCH.

18. Theunissen, G., Plaute, W. (1995). Empowerment und Heilpädagogik. Freiburg: Lambertus-Verlag.

19. Thomson, J. R., Meadan, H., Fensler, K. W., Alber, S. B., Balogh, P. A. (2007). Family Assessment Portfolios. Teaching Exceptional Children, 39(6), 19 - 25. 
20. Thousand, J., Villa, R. A., Paolucci-Whitcomb, P. E., Nevin, A. (1996). A Rationale for Collaborative Consultation. In: W. Stainback, S. Stainback (Eds.), Controversial Issues Confronting Special Education: Divergent Perspectives. Boston: Allyn \& Bacon, $223-232$.

21. Усанова, О.Н.(2006). Специальная психология. СанктПетербург: Питер.

22. Целуйко, В. М. (2004). Bbl и ваши дети: психология семьи. Ростов-на-Дону: Феникс.

23. Шнейдер, Л. Б. (2008). Семейная психология. Москва: Академический проспект.

Dr.paed., Bethere Dina Liepaja University, 14, Liela Street, Liepaja, LV 3401 Email: dina.bethere@liepu.lv

Dr.paed., Linda Pavitola Liepaja University, 14, Liela Street, Liepaja, LV 3401 Email: linda.pavitola@liepu.lv 